\title{
Isolation and antidiabetic Activity of Prenylated Xanthones from Pericarp of Mangosteen (Garacinia Mangostana Linn.)
}

\author{
Syahdam Karneng, Arif Fadlan, and Taslim Ersam \\ Department of Chemistry, Institut Teknologi Sepuluh Nopember, Surabaya \\ e-mail:paktichem@gmail.com
}

\begin{abstract}
Abstrak-The material used in this research was dry powder of pericarp mangosteen (Garcinia mangostana Linn.). which is a family plant of Clusiaceae. This taxa is known as the main source of prenylated xanthones derived from phenolic compounds. The compounds separation process was carried out by maceration method, $8 \mathrm{~kg}$ of sample macerated using $\mathrm{n}$-hexane solvent, $90 \mathrm{~g}$ of n-hexane extract were produced. The n-hexane extract was fractionated by vacuum liquid chromatography (VLC) using silica gel, eluted by increasing the polarity of the solvent, which is a mixture of n-hexane solvent: dichloromethane $(10 \%, 20 \%, 30 \%$ and $50 \%$ ), resulting in three combined fractions, namely the first fraction $13,92 \mathrm{~g}$, the second fraction $18,27 \mathrm{~g}$, and the third fraction $23,24 \mathrm{~g}$. The refraction process was then carried out in the third fraction, producing two yellow crystals with melting points respectively, $155-156{ }^{\circ} \mathrm{C}$ and $172-173{ }^{\circ} \mathrm{C}$. The structural elucidation method was carried out using UV-Vis, IR, HR-ESIMS, and NMR spectroscopy techniques. Based on the analysis of spectrum data from two known compounds, 8-deoxygartanin (1) and $\beta$-mangostin (2) antidiabetic bioactivity test was carried out by the method of inhibiting the enzyme $\alpha$-glucosidase in vitro. The test results obtained by compound (1) with an $\mathrm{IC}_{50}$ value of 38,5 $\mu \mathrm{M}$ and compound (2) with an $\mathrm{IC}_{50}$ value of $157,9 \mu \mathrm{M}$ indicate that the two compounds are included in the inactive category. This is indicated by the $\mathrm{IC}_{50}$ value which is much higher when compared to the acarbose as a positive control with an $\mathrm{IC}_{50}$ value of $4.5 \mu \mathrm{M}$.
\end{abstract}

Kata Kunci-Garcinia mangostana Linn, Isolation, antidiabetic.

\section{INTRODUCTION}

A ROUND 30,000 types of medicinal plants are known in Indonesia and $25 \%$ of them are known to have herbal properties. Data from the World Health Organization (World Helath Organization, WHO) in 2001 revealed that $80 \%$ of Indonesia's population consumed herbal medicines. This consumption nationally increases an average of 5\% per year based on the combined data of Indonesian herbal medicine and medicine entrepreneurs in 2018 [1]. This encourages scientists to continue to conduct research and exploration of various types of plants. Taksa Garcinia is a group of plants from the clusiaceae family which is estimated to have around 418 species, and 64 of them are scattered in the territory of Indonesia. Where the largest population is from Garcinia mangostana Linn. or commonly known as fruit plants, namely Mangosteen [2]. Mangosteen thrives in areas with high humidity and relatively short summers such as Indonesia. This plant lives at an altitude of $1000 \mathrm{~m}\left(20-40{ }^{\circ} \mathrm{C}\right)$ in the tropics and grows optimally in the lower plains. Mangosteen is widely used in health fields such as stomach pain, chronic ulcers, infected wounds, pus, diarrhea, cancer, heart disease and other degenerative diseases. Mangosteen also shows antiviral, antiinflammatory, antibacterial, antioxidant, antitumoral, and hypo-allergenic activity [3-4].

The various benefits and activities are due to the presence of secondary metabolite compounds contained in the Mangosteen plant. Secondary metabolites generally act as attractants, protectants, and repellants to various environmental conditions. Secondary metabolite compounds also specifically function as a protective plant against biotic pressure (bacteria, fungi, nematodes, insects, or other animals) and abiotics (temperature and humidity) [5-6]. Secondary metabolites in the mangosteen plant are generally in the form of flavonoids, tannins and xanthones, where xanthones are found in the mangosteen rind. Santon is a polyphenol with a unique and attractive structure in the form of aromatic with three cyclic, C6-C3-C6 [7].

Exploration of secondary metabolite compounds from various plant sources is very important to be continuously carried out and tested for its bioactivity due to the increasing need for medicinal preparations, so a bioactivity test method is needed in order to see the activeness of a compound. The literature review informs that so far there have been no reports of antidiabetic activity testing of the $\beta$-mangostin and 8deoxygartanin compounds. Based on this, this research was formulated to isolate secondary metabolite compounds from pericarp of mangosteen extract in the form of $\beta$-mangostin and 8 -deoxygartanin. Subsequent research was followed by an $\alpha$ glucosidase enzyme inhibitory activity test.

\section{MATERIALS AND METHOD}

\section{A. Material}

The equipment used in this study were glass beaker equipment, two neck flasks $(5 \mathrm{~mL}$ and $10 \mathrm{~mL})$, Merck TLC plate with $60 \mathrm{~F}_{254}$ silica gel (Merck KGaA 64271, Darmstadt, Germany), digital balance (Fujitsu FS-AR210, Japan), reflux (steam bath), percolator, Cimarec hot plate (SP131320-33, China), maceration tube (maserator), rotary evaporator (Buchi R-210, Switzerland), Fisher John melting point Apparatus 


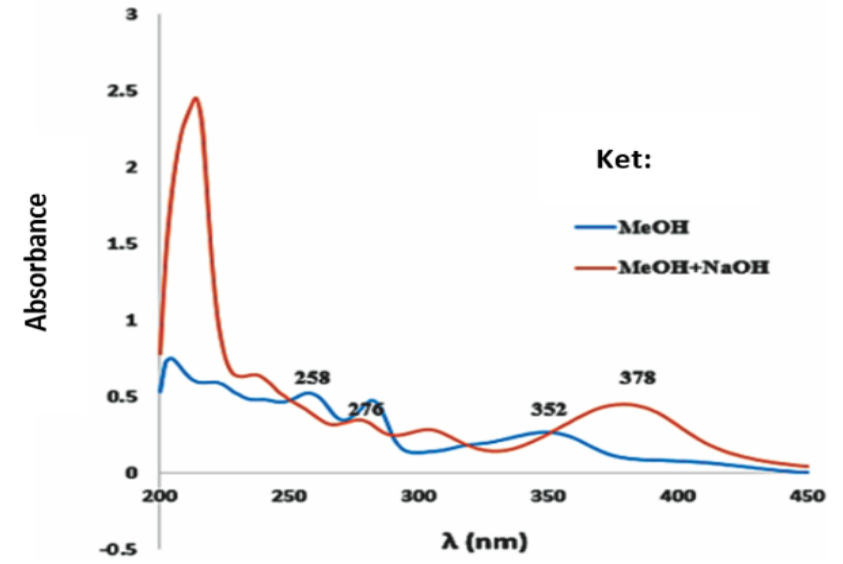

Figure 1. UV- Vis spectrum of compound 1 in $\mathrm{MeOH}$ and with the addition of $\mathrm{NaOH}$ shear reagents.



Figure 2. UV-Vis spectrum of compound 1 in $\mathrm{MeOH}$ solvents and with the addition of $\mathrm{AlCl} 3$ and $\mathrm{HCl}$ shear reagents.

(Philip Haris, USA), equipment vacuum liquid chromatography $(\mathrm{KCV})$, gravity column chromatography (KKG), sephadex column chromatography, UV lamps ( $\lambda=254$ and $366 \mathrm{~nm})$, UVVis Genesys 10S spectrometers (Thermofisher, USA), FT-IR spectrophotometer (Shimadzu 8400S, Japan), HR-EI-MS (ThermoFinnigan, Bremen, Germany) and 1H-NMR and 13CNMR (1D) spectrometers (JEOL ECS, $400 \mathrm{MHz}$, Japan).

The materials used in the study were dried pericarp of mangosteen ( $G$. mangostana L.), $n$-hexane solvent, dichloromethane, ethyl acetate, methanol, aquades, hydrochloric acid, $99 \%$ ethanol, Merck $60 \mathrm{G}$ silica gel for $\mathrm{KCV}$, silica gel 60 (70-230 mesh) for KKG, silica gel $60 \mathrm{GF}_{254}$ as a stationary phase on the TLCp plate, reagent visibility of cerium sulfate $\left(\mathrm{Ce}(\mathrm{SO} 4)_{2}\right) 1.5 \%$ in sulfuric acid $(\mathrm{H} 2 \mathrm{SO} 4) 2 \mathrm{~N}$, shear reagents for $\mathrm{UV}$ test namely $\mathrm{NaOH}, \mathrm{AlCl}_{3}$ and $\mathrm{HCl}$, acetone$d 6$, methanol- $d 4$, dimethyl sulfoxide- $d 6$ and tetramethylsilane (TMS) as a reference, and potassium bromide for IR testing.

\section{B. Isolation}

\section{1) Preliminary Test}

The preliminary test is carried out as initial data or as a reference for the next stage of the separation process. The important thing to note in this process is determining the type of solvent to be used and how effective the solvent is in the

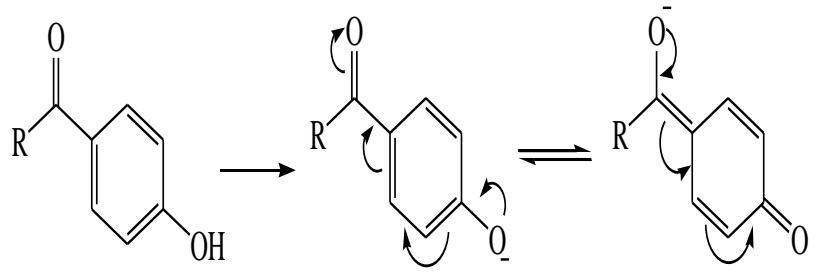

Figure 3. Interim conclusions of the structure of compound 1 based on the UV-Vis spectrum.

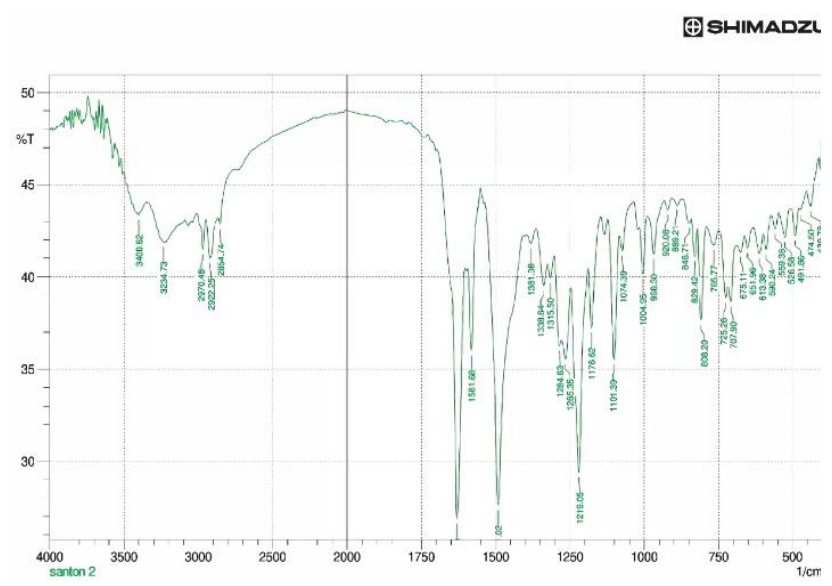

Figure 4. IR spectrum of compound 1.

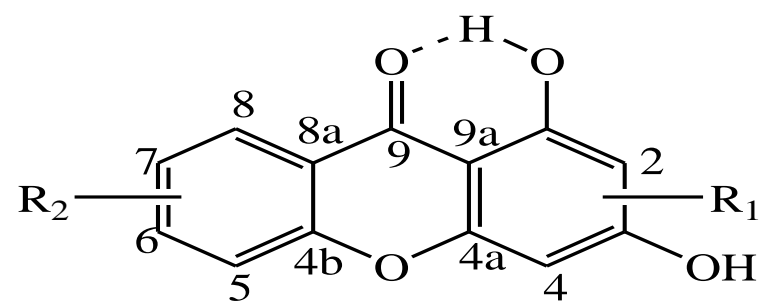

Figure 5. Suggested structural framework for compound 1 results from spectrum analysis (UV-Vis and IR).

extraction process. Samples of dried pericarp of mangosteen (G. mangostana L.) peels were milled into four vial bottles (100 $\mathrm{mL}$ ) of each bottle of 10 grams. Then the extraction process was carried out by maceration method for 24 hours using different solvents ( $n$-hexane, dichloromethane, ethyl acetate and methanol) for each vial vial.

\section{2) Extraction and Fractionation}

Dry sample powder $(8 \mathrm{~kg})$ was extracted by maceration method using $n$-hexane solvent for $3 \times 24$ hours at room temperature. Next, a filtering process is carried out to obtain the filtrate, then the filtrate is evaporated using the Eyela N-100 rotary evaporator. This process aims to separate the filtrate from the solvent, so that a thick extract of the sample is obtained.

The next process is fractionation, where the first fractionation is used vacuum liquid chromatography (VLC). The stationary phase used is $60 \mathrm{G}$ silica gel and the mobile phase is in the form of an eluent (done with an increasing polarity system). From the results of VLC fractionation obtained fractions that are accommodated in vial bottles $(300 \mathrm{~mL})$, then at thin layer chromatography (TLC) and observed its separation 
The $6^{\text {th }}$ International Seminar on Science and Technology (ISST) 2020

July $25^{\text {th }} 2020$, Institut Teknologi Sepuluh Nopember, Surabaya, Indonesia

Table 1.

NMR 8-deoxygartanin data and compound 1 in acetone d6

\begin{tabular}{|c|c|c|c|c|}
\hline \multirow{2}{*}{ Position } & \multicolumn{2}{|c|}{ 8-deoxygartanin } & \multicolumn{2}{|c|}{ Compound 1} \\
\hline & $\delta \mathrm{H}$ & $\delta \mathrm{C}$ & $\delta \mathrm{H}$ & $\delta \mathrm{C}$ \\
\hline 1 & - & 159.8 & - & 158.8 \\
\hline 2 & - & 111.6 & - & 111.6 \\
\hline 3 & - & 162.0 & - & 162.4 \\
\hline 4 & - & 107.8 & - & 107.7 \\
\hline $4 a$ & - & 153.9 & - & 153.6 \\
\hline $4 b$ & - & 146.8 & - & 145.0 \\
\hline 5 & - & 147.6 & - & 154.2 \\
\hline 6 & $\begin{array}{c}7.38(1 \mathrm{H}, \mathrm{dd}, \\
J=7.9 \text { and } 1.6)\end{array}$ & 121.6 & $\begin{array}{c}6.58(1 \mathrm{H}, \mathrm{dd}, J \\
=8.4)\end{array}$ & 108.3 \\
\hline 7 & $\begin{array}{c}7.26(1 \mathrm{H}, \mathrm{t} \\
J=7.9)\end{array}$ & 124.9 & $\begin{array}{c}7.22(1 \mathrm{H}, \mathrm{t}, J= \\
7.9)\end{array}$ & 132.7 \\
\hline 8 & $\begin{array}{c}7.70(1 \mathrm{H}, \mathrm{dd}, \\
J=7.9 \text { and } 1.6)\end{array}$ & 116.6 & $\begin{array}{l}7.65(1 \mathrm{H}, \mathrm{dd}, J \\
=8.0 \text { and } 1.3)\end{array}$ & 109.9 \\
\hline $8 \mathrm{a}$ & - & 122.5 & - & 122.9 \\
\hline 9 & - & 182.5 & - & 185.9 \\
\hline $9 \mathrm{a}$ & - & 104.2 & - & 102.7 \\
\hline 1 ' & $\begin{array}{c}3.46(2 \mathrm{H}, \mathrm{s}, \\
J=7.0)\end{array}$ & 22.8 & $\begin{array}{c}3.40(2 \mathrm{H}, \mathrm{d}, \\
\quad J=7,1)\end{array}$ & 22.2 \\
\hline $2^{\prime}$ & $\begin{array}{c}5.31(1 \mathrm{H}, \mathrm{t} \\
J=7.0 \text { dan } \\
1.3)\end{array}$ & 123.6 & $\begin{array}{c}5.24(1 \mathrm{H}, \mathrm{t} \\
J=7.0)\end{array}$ & 124.6 \\
\hline 3 , & - & 133.0 & - & 138.0 \\
\hline 4 ' & $1.67(3 \mathrm{H}, \mathrm{d})$ & 26.3 & $1.76(3 \mathrm{H}, \mathrm{s})$ & 26.0 \\
\hline 5 ' & $1.87(3 \mathrm{H}, \mathrm{d})$ & 18.5 & $\begin{array}{c}1.63-1.62(3 \mathrm{H} \\
\mathrm{m})\end{array}$ & 18.1 \\
\hline $6^{\prime}$ & $\begin{array}{c}3.69(2 \mathrm{H}, \mathrm{s}, \\
J=7.0)\end{array}$ & 22.5 & $\begin{array}{c}3.62(2 \mathrm{H}, \mathrm{d} \\
J=7.0)\end{array}$ & 22.0 \\
\hline 7 ' & $\begin{array}{c}5.25(\mathrm{t}, J=7.0 \\
\text { and } 1.3)\end{array}$ & 123.4 & $5.18(\mathrm{t}, J=7.0)$ & 122.7 \\
\hline 8 & - & 132.9 & _ & 132.8 \\
\hline $9^{\prime}$ & $1.66(3 \mathrm{H})$ & 26.2 & $1.82(3 \mathrm{H}, \mathrm{d})$ & 25.9 \\
\hline $10^{\prime}$ & $1.80(3 \mathrm{H})$ & 18.4 & $2.01(3 \mathrm{H}, \mathrm{m})$ & 18.0 \\
\hline $1-\mathrm{OH}$ & $13.33(1 \mathrm{H}, \mathrm{s})$ & - & $13.29(1 \mathrm{H}, \mathrm{s})$ & - \\
\hline $3-\mathrm{OH}$ & $6.58(1 \mathrm{H}, \mathrm{s})$ & - & $12.29(1 \mathrm{H}, \mathrm{s})$ & - \\
\hline $5-\mathrm{OH}$ & $5.56(1 \mathrm{H}, \mathrm{brs})$ & - & $11.27(1 \mathrm{H}, \mathrm{s})$ & - \\
\hline
\end{tabular}

profile. The fractions that have the same retention factor $(R f)$ value are combined, so that a smaller number of fractions will be obtained. The second fractionation was carried out using the gravity column chromatography (GCC) method. The selected fraction (chosen based on observations of the chromatogram) from the VLC fractionation was fractionated with GGC using 70-230 mesh silica gel as the stationary phase. From the GGC results fractions will be obtained (the same treatment as the VLC). The end result of the fractionation separation process is expected to be a pure compound. The purity test was carried out by the 3 -system system TLC, the 2D TLC and the melting point test.

\section{Characterization of The Isolated Metabolites}

The pure compounds obtained were determined using ultraviolet visible (UV-Vis), infrared (IR), mass (MS), and Nuclear Magnetic Resonance (NMR) spectroscopy.

\section{Antidiabetic Test}

The antidiabetic test is carried out by the $\alpha$-glucosidase inhibition test method [8]. using rat intestinal acetone powder, buffer phosphate solution ( $\mathrm{pH}$ 6.9), and a substrate in the form of sucrose. The test process was carried out by adding $10 \mu \mathrm{L}$ DMSO to eppendorf 1-4 followed by the addition of $50 \mu \mathrm{L}$

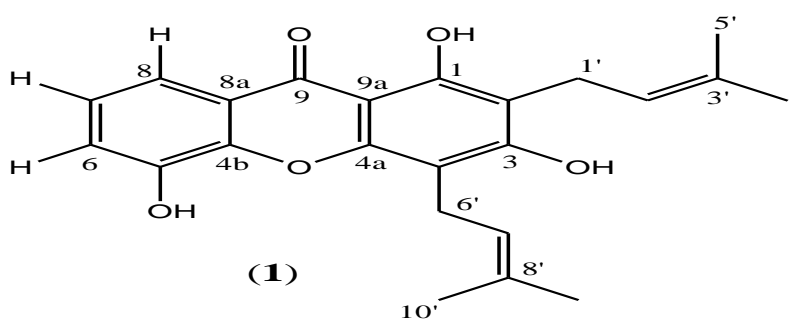

Figure 6. Compounds (1).



Figure 7. UV-Vis spectrum of compound 2 in $\mathrm{MeOH}$ solvents and with the addition of $\mathrm{NaOH}$ shear reagents.



Figure 8. Interim conclusions of the structure of compound 2 based on the UV-Vis spectrum.

buffer phosphate $(\mathrm{pH}$ 6.9) to eppendorf 1 and 3 , and $30 \mu \mathrm{L}$ buffer phosphate (pH 6.9) to eppendorf 2 and 4. Sucrose substrate $(20 \mu \mathrm{L})$ was then added to eppendorf 2 and 4 . Glucose kit $(80 \mu \mathrm{L})$ and enzyme $(20 \mu \mathrm{L})$ were then added to all eppendorf, and eppendorf was incubated for 10 minutes at 37 ${ }^{\circ} \mathrm{C}$. After incubation, absorption is measured at wavelength $(\lambda)$ $520 \mathrm{~nm}$. Inhibitory activity (\%) can be calculated through the equation:

Inhibition $(\%)=\left[\frac{\text { A.blank-A.sample }}{\text { A.blank }}\right] \times 10$

\section{RESULTS AND DISCUSSION}

\section{A. Preliminary Test}

The preliminary test in this study aims to find out the right solvent in the extraction process. The extraction results of the pericarp of mangosteen (G. mangostana L.) obtained was then monitored by the TLC method to see the profile of the stain. Appears on the TLC chromatogram showing a good separation profile of the compound, namely the $n$-hexane solvent. Therefore, in the sample extraction process an $n$-hexane solvent will be used. 


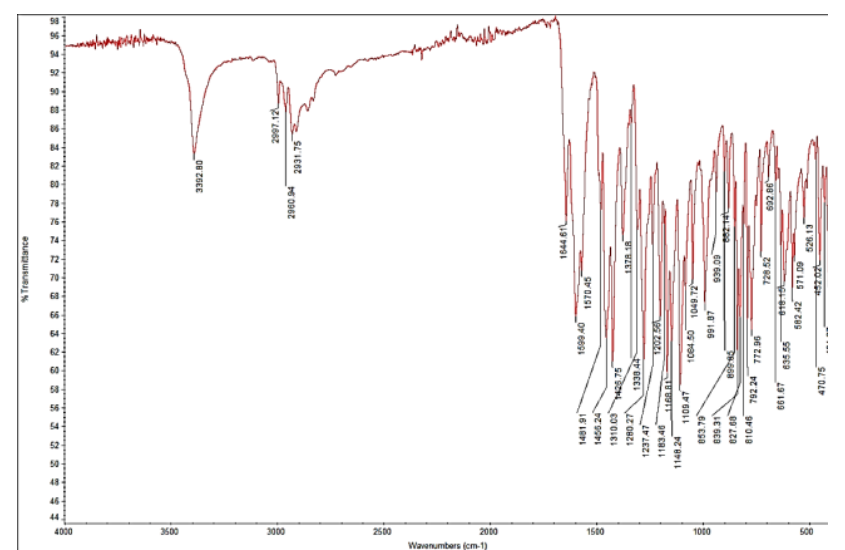

Figure 9. IR spectrum of compound 2.

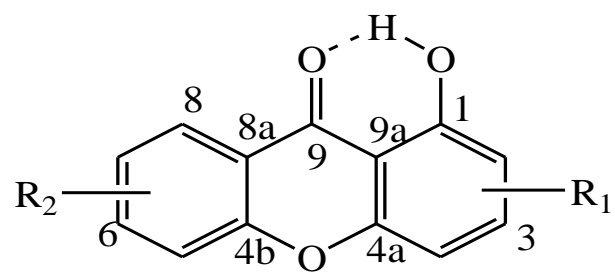

Figure 10. Suggested structural framework for compound 2 results from spectrum analysis (UV-Vis and IR).

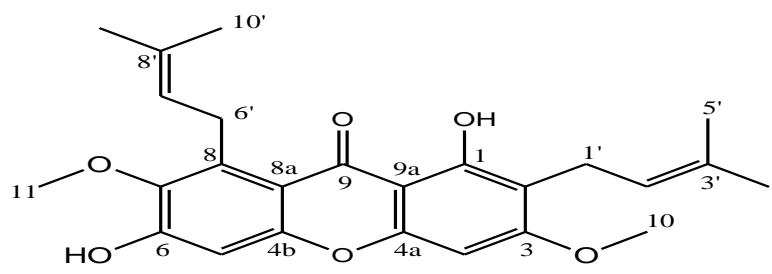

(2)

Figure 11. Compounds (2).

\section{B. Extraction and Fractionation}

$8 \mathrm{~kg}$ of samples was macerated for $3 \times 24$ hours. Maceration results obtained liquid extract which is then evaporated using an evaporator and obtained a weight of 90 grams (1.125\%). Furthermore, fractionation by the liquid-vacuum VLC method uses a mixture of $n$-hexane and methylene chloride solvent. The VLC process is carried out with an increasing polarity system, which increases eluent polarity. The result was obtained as many as 70 fractions, which then the factions were monitored by TLC, stains that have the same Rf combined. In fraction 3 yellow crystal are formed, so they are separated from the solvent by vacuum filtering. The crystal obtained was coded crystal $1(3 \mathrm{~A})$ as much as $84.20 \mathrm{mg}$, while the solvent was coded 3B. Furthermore, the combined fraction was evaporated with a rotary evaporator, to obtain 3 combined fractions, namely $1(13.92 \mathrm{~g}), 2(18.27 \mathrm{~g})$ and 3B $(23.24 \mathrm{~g})$.

The 3B fraction of $23.24 \mathrm{~g}$ was fractionated again by the VLC method. The results of this fractionation obtained by crystal and coded crystal 2 (3B5A) of $674.30 \mathrm{mg}$. Furthermore, the other fractions are combined based on the stain profile, to obtain 5 combined fractions, namely 3B1 $(0.84 \mathrm{~g}), 3 \mathrm{~B} 2(0.83$
Table 2.

Data NMR $\beta$-mangostin and compound 2

\begin{tabular}{|c|c|c|c|c|}
\hline \multirow{2}{*}{ Position } & \multicolumn{2}{|c|}{$\beta$-mangostin } & \multicolumn{2}{|c|}{ Compound $\mathbf{2}$} \\
\hline & $\delta \mathrm{H}$ & $\delta \mathrm{C}$ & $\delta \mathrm{H}$ & $\delta \mathrm{C}$ \\
\hline 1 & - & 160.5 & - & 163.2 \\
\hline 2 & - & 111.8 & - & 110.3 \\
\hline 3 & - & 164.6 & - & 158.9 \\
\hline 4 & $6.47(\mathrm{~s})$ & 89.9 & $6.55(\mathrm{~s}, 1 \mathrm{H})$ & 89.5 \\
\hline $4 a$ & - & 157.5 & - & 157.2 \\
\hline $4 b$ & - & 156.2 & - & 154.7 \\
\hline 5 & $6.83(\mathrm{~s})$ & 102.7 & $6.79(\mathrm{~s}, 1 \mathrm{H})$ & 102.7 \\
\hline 6 & - & 156.3 & - & 154.7 \\
\hline 7 & . & 144.6 & - & 143.5 \\
\hline 8 & - & 138.2 & - & 136.5 \\
\hline $8 \mathrm{a}$ & - & 112.2 & - & 110.3 \\
\hline 9 & - & 182.9 & - & 181.5 \\
\hline $9 a$ & - & 104.2 & - & 102.7 \\
\hline 10 & $3.95(\mathrm{~s})$ & 61.4 & $3.86(\mathrm{~s}, 3 \mathrm{H})$ & 60.2 \\
\hline 11 & $3.80(\mathrm{~s})$ & 56.5 & $3.68(\mathrm{~s}, 3 \mathrm{H})$ & 56.3 \\
\hline 1 ' & $\begin{array}{l}3.31(\mathrm{~d}, \\
J=7.15)\end{array}$ & 25.9 & $\begin{array}{c}3.18(\mathrm{~d}, J=7.1 \\
2 \mathrm{H})\end{array}$ & 25.7 \\
\hline $2^{\prime}$ & $5.22(\mathrm{t})$ & 123.4 & $5.09(\mathrm{t}, 1 \mathrm{H})$ & 122.2 \\
\hline 3 , & - & 131.5 & - & 130.8 \\
\hline 4, & $1.77(\mathrm{~s})$ & 25.9 & $1.69(\mathrm{~s}, 3 \mathrm{H})$ & 25.6 \\
\hline 5, & $1.82(\mathrm{~s})$ & 18.3 & $1.75(\mathrm{~s}, 3 \mathrm{H})$ & 17.6 \\
\hline $6^{\prime}$ & $4.12(\mathrm{~d}, J=6.5)$ & 21.9 & $\begin{array}{c}3.98(\mathrm{~d}, J=6.5 \\
2 \mathrm{H})\end{array}$ & 20.9 \\
\hline $7^{\prime}$ & $5.28(\mathrm{t})$ & 124.7 & $5.13(\mathrm{t}, 1 \mathrm{H})$ & 123.6 \\
\hline $8^{\prime}$ & - & 131.5 & - & 130.5 \\
\hline 9, & $1.63(\mathrm{~s})$ & 17.9 & $1.58(\mathrm{~s}, 3 \mathrm{H})$ & 18.0 \\
\hline 10 & $1.65(\mathrm{~s})$ & 26.9 & $1.59(\mathrm{~s}, 3 \mathrm{H})$ & 25.7 \\
\hline $1-\mathrm{OH}$ & $13.61(\mathrm{~s})$ & - & $13.56(\mathrm{~s}, 1 \mathrm{H})$ & - \\
\hline $6-\mathrm{OH}$ & $8.21(\mathrm{~s}, 1 \mathrm{H})$ & - & $8.28(\mathrm{~s}, 1 \mathrm{H})$ & - \\
\hline
\end{tabular}

g), 3B3 (3.31 g), 3B4 (3.55 g) and 3B5B (6.09 g). The fractions of $3 \mathrm{~B} 3(3.31 \mathrm{~g})$ and $3 \mathrm{~B} 4(3.55 \mathrm{~g})$ were further fractionated by the sephadex column chromatography method. Sephadex column chromatography is a fractionation method based on differences in molecular size of compounds. Fractionation was carried out using methylene chloride-methanol (50\%) eluent. The results of fractionation of sephadex column produced 5 main fractions for 3B3, namely 3B3A $(20.20 \mathrm{mg})$, 3B3B $(361.60 \mathrm{mg}), 3 \mathrm{~B} 3 \mathrm{C}(158.60 \mathrm{mg}), 3 \mathrm{~B} 3 \mathrm{D}(1.23 \mathrm{~g})$ and $3 \mathrm{~B} 3 \mathrm{E}$ $(1.34 \mathrm{~g}))$ and 4 main fractions for 3B4, namely 3B4A (180.70 $\mathrm{mg}), 3 \mathrm{~B} 4 \mathrm{~B}(381.80 \mathrm{mg}), 3 \mathrm{~B} 4 \mathrm{C}(382.20 \mathrm{mg})$ and 3B4D $(1.11 \mathrm{~g})$. The 3B3E $(1.34 \mathrm{~g})$ and 3B4D $(1.11 \mathrm{~g})$ fractions was combined because they had a similar Rf value and were named the " $\mathrm{X}$ " fraction, then was refracted by the GCC method, so that 5 main fractions (X1-X5). The results of this fractionation produced two crystal, namely crystal 3 as much as $256.50 \mathrm{mg}$ and crystal 4 as much as $290 \mathrm{mg}$, each of which came from fractions X4 and X5.

Crystal purity test $1(3 \mathrm{~A})$, crystal 2 (3B5A), crystal 3 (x4) and crystal 4 (x5) with TLC method 3 eluent system obtained a single stain appearance on each different eluent. The melting points of crystals are $155-156{ }^{\circ} \mathrm{C}, 156-157{ }^{\circ} \mathrm{C}, 155-156^{\circ} \mathrm{C}$ and $172-173{ }^{\circ} \mathrm{C}$, respectively. Crystals 1 (3A), 2 (3B5A), and 3 (x4) have similarities in terms of shape, color, melting point and $\mathrm{Rf}$ value, so that the three crystals are inferred to be the same crystal and coded as compound 1. Meanwhile, crystals 4 is different from other crystals, so it is coded compound 2. 

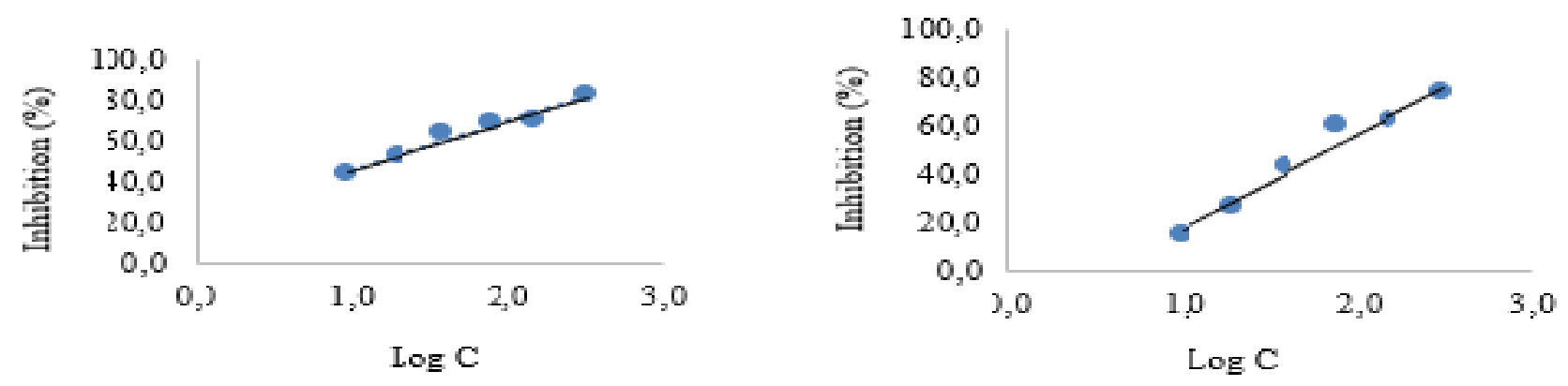

Figure 12. Inhibition of $\alpha$-glucosidase (a) compounds (1); (b) compound (2).

Tabel 3.

$\mathrm{IC}_{50}$ value $(\mu \mathrm{M})$ 8-deoxygartanin (1), $\beta$-mangostin (2), dan acarbose (+)

\begin{tabular}{|c|c|c|c|c|}
\hline \multirow[b]{2}{*}{ Concentration (C) } & \multirow[b]{2}{*}{$\log C$} & \multicolumn{3}{|c|}{ Inhibition (\%) } \\
\hline & & $\begin{array}{c}\text { 8-deoxygartanin } \\
\text { (1) }\end{array}$ & $\begin{array}{c}\beta \text {-mangostin } \\
\text { (2) }\end{array}$ & $\begin{array}{c}\text { Acarbosa } \\
(+)\end{array}$ \\
\hline 312.50 & 2.495 & 83.22 & 73.88 & - \\
\hline 156.25 & 2.194 & 70.28 & 61.98 & - \\
\hline 78.12 & 1.893 & 68.88 & 59.75 & - \\
\hline 39.06 & 1.592 & 64.34 & 42.75 & - \\
\hline 19.53 & 1.291 & 52.40 & 26.77 & - \\
\hline 9.77 & 0.990 & 44.18 & 14.98 & - \\
\hline \multicolumn{2}{|c|}{$\mathbf{Y}$} & $24.05 x+21.98$ & $39.59 x-22.29$ & - \\
\hline \multirow{2}{*}{\multicolumn{2}{|c|}{$\begin{array}{c}\mathbf{R}^{2} \\
\mathbf{I C}_{50}(\mu \mathrm{M})\end{array}$}} & 0.9553 & 0.9704 & - \\
\hline & & 38.5 & 157.9 & 4.5 \\
\hline
\end{tabular}

* Positive control (+) acarbose.

\section{Characterization of the Isolated Metabolites}

\section{1) Compound 1}

Compound 1 was identified using UV-Vis, IR, $1 \mathrm{H}-\mathrm{NMR}$ and 13C-NMR spectroscopic methods. The UV-Vis spectrum of compound 1 shows the presence of two peaks at wavelengths ( $\lambda$ ) of $258 \mathrm{~nm}$ and $352 \mathrm{~nm}$ (Figure 1). The absorption peak at $\lambda$ $258 \mathrm{~nm}$ indicates the electron transition $\pi \rightarrow \pi *$ which is a typical chromophore conjugated double bond $(-\mathrm{C}=\mathrm{C}-\mathrm{C}=\mathrm{C}-)^{2}$ aromatic ring and the $352 \mathrm{~nm}$ absorption peak shows the electron transition $\mathrm{n} \rightarrow \pi *$ heteroatom that is conjugated with a bond duplicate $(-\mathrm{C}=\mathrm{C}-\mathrm{C}=\mathrm{O})$. These data provide an initial conclusion that compound 1 contains an aromatic system substituted for ketones.

Further testing is carried out using UV shear reagents to determine the position of the substituted hydroxy group located in the ortho- or para- position. The addition of $\mathrm{NaOH}$ shear reagents caused a batochromic shift where the peak at $\lambda 258 \mathrm{~nm}$ shifted to $276 \mathrm{~nm}$ and the peak at $\lambda 352 \mathrm{~nm}$ shifted to $378 \mathrm{~nm}$. The existence of this peak shift informs that the hydroxy group is substituted in a para-position due to keto-enol equilibrium. Furthermore, the addition of $\mathrm{AlCl}_{3}$ shear reagents also caused a batochromic shift, the peak at $\lambda 352 \mathrm{~nm}$ shifted to $368 \mathrm{~nm}$ and the peak at $\lambda 258 \mathrm{~nm}$ shifted to $266 \mathrm{~nm}$ (Figure 2). This shift indicates that compound 1 is substituted by a hydroxy group ($\mathrm{OH})$ which is chelated with carbonyl $(-\mathrm{C}=\mathrm{O})$. The addition of $\mathrm{HCl}$ shear reagents subsequently did not cause a shift in the absorption peak. This indicates that in crystal 1 there is a hydroxy group chelated with carbonyl under stable conditions.
Analysis of UV-Vis compound 1 gives a provisional conclusion containing a hydroxy group (-OH) in the para- position of the carbonyl suggested that keto-enol or tautomery equilibrium in the aromatic ring is expected (Figure 3).

IR spectroscopic analysis of compound 1 as can be seen in Figure 4. shows the absorption band at the wave number $\left(\mathrm{v}, \mathrm{cm}^{-}\right.$ 1) $3404 \mathrm{~cm}^{-1}$ which characterizes the presence of a hydroxy group (-OH) and absorption band at $1629 \mathrm{~cm}^{-1}$ which is suitable for the group carbonyl $(\mathrm{C}=\mathrm{O})$ chelated $-\mathrm{OH}$ group, typical for phenolic or xanthone skeletons [9-10]. The IR analysis data supports the results of the analysis using UV-Vis spectroscopy which shows the absorption peak at $\lambda 352 \mathrm{~nm}$ which indicates the existence of a heteroatomic conjugation system in the aromatic ring. IR spectrum data of compound 1 also gave absorption bands at $2970 \mathrm{~cm}^{-1}, 2922 \mathrm{~cm}^{-1}$, and $2854 \mathrm{~cm}^{-1}$ which are methyl groups (aliphatic $-\mathrm{CH}$ ). Other absorption bands were also seen at $1581 \mathrm{~cm}^{-1}, 1491 \mathrm{~cm}^{-1}, 1381 \mathrm{~cm}^{-1}, 1338 \mathrm{~cm}^{-1}$, which showed a double bond in the aromatic ring, reinforcing UV-Vis data at $\lambda 258 \mathrm{~nm}$ [11-12]. Then, the absorption band at $1220 \mathrm{~cm}^{-}$ ${ }^{1}$ is suitable for the ether group (C-O). The results of the combined UV-Vis and IR analysis can be suggested that compound 1 has: the basic framework of xanthone compounds containing chelated hydroxy groups with carbonyl groups in the ortho position and hydroxy groups in the para-to carbonyl position, as shown in (Figure 5).

Identification of compound 1 was followed by mass spectroscopy (High Resolution Electrospray Ionization Mass Spectrometry, HR-ESI-MS). The spectrum shows a peak at $\mathrm{m} / \mathrm{z}$ $381.2993[\mathrm{M}+\mathrm{H}]^{+}$. Based on these data, it can be assumed that 
compound 1 has the molecular formula $\mathrm{C}_{23} \mathrm{H}_{25} \mathrm{O}_{5}$ from the calculation of MS 381,3005 with a DBE value of 11.5. Further structural identification using ${ }^{1} \mathrm{H}-\mathrm{NMR}$ spectroscopy (400 $\mathrm{MHz}$, acetone $d 6$ ), continuing the results of UV-Vis, IR and HR-ESI-MS analysis of xanthone compounds showed the presence of an unshielded singlet signal (downfield) on chemical shifts $(\delta \mathrm{H}) 13.29 \mathrm{ppm}$ which is suitable for one proton chelate hydroxy group on a C-1 atom. Furthermore, three aromatic protons appear as doublets of doublet at $\delta \mathrm{H} 7.65 \mathrm{ppm}$, $7.22 \mathrm{ppm}$, and $6.58 \mathrm{ppm}$. Two free hydroxy protons each appear as singlets at $\delta \mathrm{H} 12.29 \mathrm{ppm}$ and $11.27 \mathrm{ppm}$. The ${ }^{1} \mathrm{H}-\mathrm{NMR}$ spectrum of compound 1 also showed the presence of two prenyl substituents which were marked by the presence of two doublet signals at $\delta \mathrm{H} 3.62 \mathrm{ppm}$ and $3.40 \mathrm{ppm}$ which were suitable for two methylene protons, two triplet signals at $\delta \mathrm{H}$ $5.24 \mathrm{ppm}$ and $5.18 \mathrm{ppm}$, each corresponding to one methyl proton, and four signals that appear at $\delta \mathrm{H} 2.01 \mathrm{ppm}, 1.82 \mathrm{ppm}$, $1.76 \mathrm{ppm}$, and $1.63 \mathrm{ppm}$ which are suitable for twelve proton methyl groups. The ${ }^{13} \mathrm{C}-\mathrm{NMR}$ spectrum $(101 \mathrm{MHz}$, acetone d6) showed 23 peaks, namely $185.9 ; 162.4 ; 158.8 ; 154.2 ; 153.6$; $145.0 ; 138.0 ; 132.7 ; 132.8 ; 124.6 ; 122.9 ; 122.7 ; 111.6 ; 109.9$; $108.3 ; 107.7 ; 102.7 ; 26.0 ; 25.9 ; 22.2 ; 22.0 ; 18.1 ; 18.0$. Furthermore, comparison of NMR data for compound 1 with NMR data for compound 8-deoxygartanin [13] as tabulated in Table 1. shows similarities between the two. Based on UV-Vis, IR, HR-ESI-MS, ${ }^{1} \mathrm{H}-\mathrm{NMR}$ and ${ }^{13} \mathrm{C}-\mathrm{NMR}$ spectroscopy it can be concluded that compound 1 has one chelate hydroxy group, two free hydroxy groups, and two prenil groups which are 8deoxygartanin compounds (1) and can see Figure 6

\section{2) Compound 2}

The UV-Vis spectrum of compound 2 shows the presence of two peaks at wavelengths $(\lambda)$ of $242 \mathrm{~nm}$ and $314 \mathrm{~nm}$ (Figure 7). As in compound 1 the two absorption peaks indicate that compound 2 contains an aromatic system substituted for ketones (Figure 8). Compound 2 does not contain a hydroxy group $(-\mathrm{OH})$ in the para-to carbonyl position because at the time of addition of the $\mathrm{NaOH}$ and $\mathrm{AlCl}_{3}$ shear reagents there is no batochromic shift.

IR spectroscopic analysis of compound 2 as can be seen in Figure 9. shows absorption bands similar to compound 1 which are characteristic of derivatives of xanthones [9-10], [12]. The results of the IR analysis provide the second conclusion that compound 2 has a framework of xanthone compounds containing chelated hydroxy groups with carbonyl groups at the ortho position (Figure 10).

Identification of compound 2 is followed by High Resolution Electrospray Ionization Mass Spectrometry, HR-ESI-MS. The MS spectrum shows a peak at $\mathrm{m} / \mathrm{z}$ 425,2026 [M + H] $]^{+}$. Based on these data, it can be assumed that compound 2 has the molecular formula $\mathrm{C}_{25} \mathrm{H}_{29} \mathrm{O}_{6}$ from the calculation of $\mathrm{MS}$ 425,1964 with a DBE value of 11.5.

Further structural identification using ${ }^{1} \mathrm{H}-\mathrm{NMR}$ spectroscopy (400 MHz, DMSO d6), continuing the results of UV-Vis, IR, HR-ESI-MS analysis of xanthone compounds showed signals similar to compound 1. However, there were slight differences in the number of peaks, where there are more peaks that appear. The peak appears as a singlet at $\delta \mathrm{H} 8.28 \mathrm{ppm}$ which is free hydroxy. At $\delta \mathrm{H} 3.86 \mathrm{ppm}$ and $3.68 \mathrm{ppm}$ each corresponding to six methoxy protons appears as singlets.

The ${ }^{13} \mathrm{C}-\mathrm{NMR}$ spectrum (101 MHz, DMSO d6), shows peaks similar to compound 1 . However, there are two additional peaks that appear at $\delta \mathrm{C} 60.2 \mathrm{ppm}$ and $56.3 \mathrm{ppm}$ which are typical for two methoxy carbon. The ${ }^{13} \mathrm{C}-\mathrm{NMR}$ spectrum data provides information that 25 peaks, namely $181.5 ; 163.2 ; 158.9 ; 157.2$; $154.7 ; 154.7 ; 143.5 ; 136.5 ; 130.8 ; 130.5 ; 123.6 ; 122.2 ; 110.3$; $110.3 ; 102.7 ; 102.7 ; 89.5 ; 60.2 ; 56.3 ; 25.7 ; 25.7 ; 25.6 ; 20.9$; $18.0 ;$ 17.6. Furthermore, comparison of NMR data for compound 2 with NMR data for $\beta$-mangostin compound [14] as tabulated in Table 2 shows the similarity between the two. Based on UV-Vis, IR, HR-ESI-MS, ${ }^{1} \mathrm{H}-\mathrm{NMR}$ and ${ }^{13} \mathrm{C}-\mathrm{NMR}$ spectroscopy it can be concluded that compound 2 has one chelate hydroxy group, one free hydroxy group, two prenyl groups and two methoxy groups which are $\beta$ - compounds mangostin (2) and can see Figure 11.

\section{Antidiabetic Test}

The test sample used 8-deoxygartanin (1) and $\beta$-mangostin (2), while the positive control used rootsbosa. The $\mathrm{IC}_{50}$ value is determined using a linear regression equation by changing the concentration into a log concentration. Calculation results can be seen in Table 3. and Figure 12.

\section{CONCLUSION}

This research has explored two phenolic compounds, 8deoxigartanin (1) and $\beta$-mangostin (2) from n-hexane extract of mangosteen rind (Garcinia mangostana Linn.). Determination of the structure of the compound is carried out utilizing UVVis, IR, HR-ESI-MS, and NMR spectroscopic techniques. The results of antidiabetic bioactivity tests on isolates 8deoxigartanin (1) and $\beta$-mangostin (2) resulted in IC50 values $=38.5 \mu \mathrm{M}$ and $157.9 \mu \mathrm{M}$, respectively.

\section{REFERENCES}

[1] Hidayat, J. S. (2018). Delivering The Vision-Laporan Tahunan. Jakarta: PT. Sido Muncul.

[2] Santoso, B., Rifqi, S. U., Muhammad, D. W. (2016). Analisis Hubungan Senyawa Golongan Flavonoid Dari 24 Famili Tanaman Terhadap Aktivitas Penangkap Radikalnya. Prosiding Seminar Nasional Kimia F.Farmasi. Surakarta: Universitas Muhammadiyah Surakarta.

[3] Pedraza-Chaverri, J., Noemi, C-R., Marisol, O-I., Jazmin, M. P-R. (2008). Review: Medicinal Properties of Mangosteen (Garcinia Mangostana L.). Food and Chemical Toxicology, 46(10), 3227-3239.

[4] Nofriati, D., Dewi, N., Herwenita. (2019). Prospek Pemanfaatan Kulit Buah Manggis Menjadi Minuman Herbal Sebagai Upaya Meningkatkan Nilai Tambah Produk (Studi Kasus Di Provinsi Jambi). In PNK BPTP Jambi, Peneliti BPTP Jambi, PNK BPTP Sum Sel.

[5] Pagare, S., Manila, B., Niraj, T., Sonal, P., Y. K., Bansal. (2015). Secondary Metabolites of Plants and Their Role: Overview. Current Trends in Biotechnology and Pharmacy Journal, 9(3), 293-304.

[6] Tiwari, R., C. S. Rana. (2015). A Review: Plant secondary metabolites. International Journal of Engineering Research and General Science, 3(5), $153-159$. 
The $6^{\text {th }}$ International Seminar on Science and Technology (ISST) 2020

July $25^{\text {th }} 2020$, Institut Teknologi Sepuluh Nopember, Surabaya, Indonesia

[7] Obolskiy, D., Ivo, P., Nisarat, S., Michael, H. (2009), Review : Garcinia mangostana L.: a Phytochemical and Pharmacological. Phytotherapy Research. Vol. 23, No. 8, 1047-1065.

[8] Fatmawati, S., Kuniyoshi, S., Ryuichiro, K. (2011). Ganoderol B: A Potent Glucosidase Inhibitor Isolated From The Fruiting Body of Ganoderma Lucidum. Phytomedicine Journal, 18(12), 1053-1055.

[9] Jung, H. A., Bao, N. S., William, J. K., Rajendra, G. M., A. Doughlas, K. (2006). Antioxidant Xanthones From The Pericarp of Garcinia mangostana (Mangosteen). Journal of Agricultural and Food Chemistry, 54(6), 20772082.

[10] Wulandari, A. W. (2017). Isolasi Dua Senyawa Santon Dari Ekstrak Batang Metilen Klorida Garcinia tetrandra Pierre. Skripsi pada FMIPA. Surabaya: Institut Teknologi Sepuluh Nopember.

[11] Jayanti, H. S. D. (2018). Digeranilasi Santon Pada Ekstrak Diklorometana
Kulit Batang Wadung (Garcinia tetranda Pierre). Skripsi pada FIA. Surabaya: Institut Teknologi Sepuluh Nopember.

[12] Ibrahim, S. R. M., Gamal, A. M., Maan, T. K., Sahar, A., Hany, A-H., Khalid, Z, A. (2019). Mangostanaxanthone Viiii, A New Xanthone From Garcinia mangostana Pericarps, $\alpha$-Amylase Inhibitory Activity, and Molecular Docking Studies. Revista Brasileira de Farmacognosia Journal, 29(2), 206-212.

[13] Nguyen, L-H, D., Hau, T, V., Hung, D, P., Joseph, D, C., Leslie, J, H. (2012). Xanthones From The Bark of Garcinia pedunculata. Phytochemistry Letters, 5(4), 766-769.

[14] Lukis, P.A. (2011). Dua Senyawa Mangostin Dari Ekstrak n-Heksana Pada Kayu Akar Manggis (Garcinia mangostana Linn.) Asal Kab. Nganjuk, Jawa Timur. In Prosiding Kimia FMIPA. Surabaya: Institut Teknologi Sepuluh Nopember. 